See Article page e353.

\section{Commentary: Fools rush in where angels fear to tread}

\author{
Joseph S. Coselli, MD
}

In this current issue of the Journal, Dr Naoto Fukunaga and associates, including the esteemed surgeon Dr Tirone David, describe a single rare case of valve-sparing aortic root replacement in a patient with a filamin A variant. ${ }^{1}$ In males, loss of function mutations within the FLNA gene are generally lethal; in females, these mutations are most commonly linked to periventricular nodular heterotopia, which is associated with joint hypermobility, variable skin characteristics, and vascular abnormalities. Patients with this rare condition commonly have aneurysms of the aortic root and ascending aorta that are often combined with a patent ductus arteriosus and ventricular septal defects.

The authors refer to the 2013 study by Reinstein and colleagues, ${ }^{2}$ who concluded that in their cohort of 11 patients with X-linked periventricular nodular heterotopia, although illustrative of the breadth of expressivity of this phenotype, they were unable to address the frequency and prevalence of cardiovascular anomalies in this condition. Subsequently, the authors refer to the most recent study, by Chen and coauthors, ${ }^{3}$ who evaluated a cohort of 114 subjects, of which 48 were original patients and 66 were subjects pulled from a review of the literature. The majority of these subjects $(\mathrm{n}=74 ; 65 \%)$ had a cardiovascular anomaly; of these, the most common cardiovascular abnormality was aortic aneurysm or pathological aortic dilatation $(n=21 ; 15$ females and 6 males). The authors note that the location of the aortic aneurysm was known in the majority of patients (19 of 21), and that in all of these patients, the aneurysm involved the aortic root and/or the ascending aorta. Furthermore, on follow-up, 2 additional patients were found to have died from "sudden aortic rupture" at autopsy. Thus,

\footnotetext{
From the Division of Cardiothoracic Surgery, Michael E. DeBakey Department of Surgery, Baylor College of Medicine; Department of Cardiovascular Surgery, Texas Heart Institute; and CHI St. Luke's Health-Baylor St. Luke's Medical Center, Houston, Tex.

Disclosures: Dr Coselli's work is partly supported by the Cullen Foundation. He consults for, receives royalties and a departmental educational grant from, and participates in clinical trials for Terumo Aortic; consults and participates in clinical trials for Medtronic and W.L. Gore \& Associates; and serves as a coinvestigator for CytoSorbents.

Received for publication April 23, 2020; revisions received April 23, 2020; accepted for publication April 24, 2020; available ahead of print May 11, 2020.

Address for reprints: Joseph S. Coselli, MD, One Baylor Plaza, BCM 390, Houston, TX 77030 (E-mail: jcoselli@bcm.edu).

J Thorac Cardiovasc Surg 2021;161:e357-8

$0022-5223 / \$ 36.00$

Copyright (c) 2020 by The American Association for Thoracic Surgery

https://doi.org/10.1016/j.jtcvs.2020.04.124
}

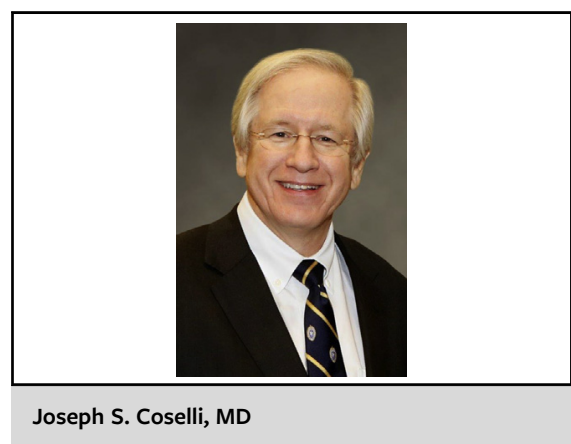

CENTRAL MESSAGE

Aortic valve-sparing techniques

in patients with the severest of

tissue fragility require special

consideration.

there is clearly an association between patients with filamin A variants and aggressive proximal aortic aneurysm.

Fukunaga and coauthors point out the rarity of having a filamin A variant as well as the extreme tissue fragility observed in their patient. They refer to their overall experience in more than 600 valve-sparing aortic root replacements and indicate that this was the only patient with this particular genetic mutation that they have encountered. Regarding tissue fragility, the authors point to the potential life-threatening complication of pseudoaneurysm formation arising from tearing of subannular tissue. In support of the mechanism of tearing subannular tissue as a source of pseudoaneurysm formation, the authors refer to the report by Liu and colleagues ${ }^{4}$ at Johns Hopkins Hospital, who describe 4 cases of pseudoaneurysm formation after valve-sparing aortic root replacement in 31 children with Loeys-Dietz syndrome. They note that the children who developed pseudoaneurysm ( 2 of which were in the periannular region) had the most severe subset of Loeys-Dietz syndrome. Two other cases of pseudoaneurysm included coronary artery dehiscence in 1 case and at the anastomosis between the aortic root graft and ascending/aortic arch graft in the other case. Consequently, only 3 of these cases of pseudoaneurysm resulted from tissue fragility, and 2 were within the aortic root. Dr Fukunaga suggests that the development of aortic root pseudoaneurysms stem from inherent tissue fragility, and in the cases detailed within the Johns Hopkins series, might stem from their technique of using only 3 subannular sutures, which may be inadequate to distribute the force associated with systolic ejection, resulting in the eventual tearing of the sutures at that level. Despite the dehiscence at the subannular level in only 2 
of 31 patients, Dr Cameron mentions that he is reassessing the use of only 3 subannular sutures in patients who have extreme tissue fragility. ${ }^{4}$

Fukunaga and coauthors ${ }^{1}$ provide a very important contribution and modification of their technique; in recognition of the extreme fragility of the commissural triangles of the noncoronary cusp, they added 3 horizontal 4-0 polypropylene mattress sutures to this "paper-thin area." They provide an illustrative drawing. The authors do not precisely state it, but they bestow a lesson for all of us. With the very wide and expanding clinical application of valve-sparing root replacement, there remain specific circumstances and genetic conditions with the severest of tissue fragility in which the technical expertise of the most experienced aortic root surgeons, including the legendary Tirone David, may be necessary to achieve the desired long-term results.

\section{References}

1. Fukunaga N, Seidman MA, David TE. Valve-sparing root replacement in a patient with a filamin A variant. J Thorac Cardiovasc Surg. 2021;161:e353-5.

2. Reinstein E, Frentz S, Morgan T, Garcia-Minaur S, Leventer RJ, McGillivray G, et al. Vascular and connective tissue anomalies associated with X-linked periventricular heterotopia due to mutations in Filamin A. Eur J Hum Genet. 2013;21: 494-502.

3. Chen MH, Choudhury S, Hirata M, Khalsa S, Chang B, Walsh CA. Thoracic aortic aneurysm in patients with loss of function Filamin A mutations: clinical characterization, genetics, and recommendations. Am J Med Genet A. 2018;176: 337-50.

4. Liu RH, Fraser CD III, Zhou X, Cameron DE, Vricella LA, Hibino N. Pseudoaneurysm formation after valve sparing root replacement in children with LoeysDietz syndrome. J Card Surg. 2018;33:339-43.
See Article page e353.

\section{Commentary: Genetics and surgical planning in heritable aortic disease - moving from "when to operate" to "how to operate"}

\begin{abstract}
Ashley Dawson, MD, ${ }^{\mathrm{a}}$ and Scott A. LeMaire, $\mathrm{MD}^{\mathrm{a}, \mathrm{b}, \mathrm{c}, \mathrm{d}}$
The efficiency and decreasing cost of genetic analysis have increased the identification of gene mutations associated with heritable thoracic aortic aneurysm and dissection
\end{abstract}

From the a Division of Cardiothoracic Surgery, Michael E. DeBakey Department of Surgery, ${ }^{\mathrm{b} C a r d i o v a s c u l a r}$ Research Institute, and ${ }^{\mathrm{c}}$ Department of Molecular Physiology and Biophysics, Baylor College of Medicine, Houston, Tex; and ${ }^{\mathrm{d}}$ Department of Cardiovascular Surgery, Texas Heart Institute, Houston, Tex.

Dr Dawson's work is supported by a fellowship award through the University of Kentucky-Baylor College of Medicine Aortopathy Research Center within the American Heart Association Strategically Focused Vascular Disease Research Network (18SFRN33960114). Dr LeMaire's work is supported in part by the Jimmy and Roberta Howell Professorship in Cardiovascular Surgery at Baylor College of Medicine.

Disclosures: The authors reported no conflicts of interest.

The Journal policy requires editors and reviewers to disclose conflicts of interest and to decline handling or reviewing manuscripts for which they may have a conflict of interest. The editors and reviewers of this article have no conflicts of interest.

Received for publication May 18, 2020; accepted for publication May 18, 2020; available ahead of print June 5, 2020.

Address for reprints: Scott A. LeMaire, MD, Division of Cardiothoracic Surgery, Michael E. DeBakey Department of Surgery, One Baylor Plaza, BCM 390, Houston, TX 77030 (E-mail: slemaire@bcm.edu).

J Thorac Cardiovasc Surg 2021;161:e358-9

$0022-5223 / \$ 36.00$

Copyright (c) 2020 by The American Association for Thoracic Surgery

https://doi.org/10.1016/j.jtcvs.2020.05.063
Check for updates

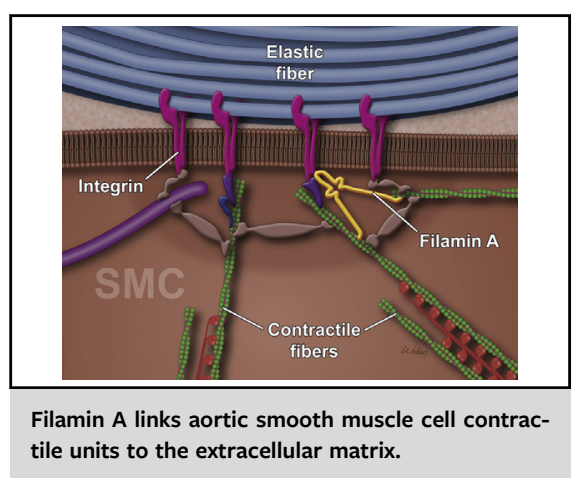

CENTRAL MESSAGE

Consistent reporting of tissue

quality and repair techniques

used in patients with heritable

aortic disease will help surgeons

develop an operative plan

tailored to a patient's genetic

mutation.

(HTAAD). Curating causative genes requires carefully evaluating the disease phenotypes associated with each mutation. ${ }^{1}$ Consistently reporting gene-specific clinical features has been important in the development of evidence-based recommendations with which to counsel patients with HTAAD and make decisions about the timing of aortic repair. ${ }^{2,3}$ From a surgeon's perspective, knowing the tissue quality and recommended repair techniques 